\title{
Symplekin and multiple other polyadenylation factors participate in 3'-end maturation of histone mRNAs
}

\author{
Nikolay G. Kolev and Joan A. Steitz ${ }^{1}$ \\ Howard Hughes Medical Institute, Department of Molecular Biophysics and Biochemistry, Yale University, \\ New Haven, Connecticut 06536, USA
}

\begin{abstract}
Most metazoan messenger RNAs encoding histones are cleaved, but not polyadenylated at their $3^{\prime}$ ends. Processing in mammalian cell extracts requires the U7 small nuclear ribonucleoprotein (U7 snRNP) and an unidentified heat-labile factor (HLF). We describe the identification of a heat-sensitive protein complex whose integrity is required for histone pre-mRNA cleavage. It includes all five subunits of the cleavage and polyadenylation specificity factor (CPSF), two subunits of the cleavage stimulation factor (CstF), and symplekin. Reconstitution experiments reveal that symplekin, previously shown to be necessary for cytoplasmic poly(A) tail elongation and translational activation of mRNAs during Xenopus oocyte maturation, is the essential heat-labile component. Thus, a common molecular machinery contributes to the nuclear maturation of mRNAs both lacking and possessing poly(A), as well as to cytoplasmic poly(A) tail elongation.
\end{abstract}

[Keywords: Symplekin; polyadenylation; 3'-end processing; U7 snRNP; histone mRNA; Cajal body]

Received September 1, 2005; revised version accepted September 12, 2005.

During the S phase of the cell cycle, histone mRNA levels are up-regulated to meet the need for histones to package newly synthesized DNA. Increased transcription of the histone genes, increased efficiency of 3 '-end formation, and stabilization of mature histone messenger RNAs all contribute (for review, see Marzluff and Duronio 2002). In metazoa, most histone transcripts are not polyadenylated. Rather, their 3' ends are produced by a simple endonucleolytic cleavage event that is not followed by polymerization of adenylate residues onto the resulting 3' -hydroxyl group (Birchmeier et al. 1984; Krieg and Melton 1984; Gick et al. 1986).

The signal for 3 ' -end processing of histone pre-mRNAs consists of a conserved stem-loop positioned upstream of the cleavage site and a purine-rich histone downstream element (HDE) (for review, see Marzluff and Duronio 2002). The HDE is recognized through base pairing to the 5' end of the U7 small nuclear RNA (Schaufele et al. 1986; Bond et al. 1991), which is incorporated into a ribnucleoprotein (RNP) of the Sm class (U7 snRNP). The stem-loop is bound by stem-loop-binding protein (SLBP), which helps recruit the U7 snRNP to the pre-mRNA (Dominski et al. 1999). A zinc finger protein (ZFP100) facilitates this recruitment (Dominski et al. 2002; Pillai et al. 2003) by bridging between SLBP and Lsm11, a

${ }^{1}$ Corresponding author.

E-MAIL joan.steitz@yale.edu; FAX (203) 624-8213.

Article published online ahead of print. Article and publication date are at http://www.genesdev.org/cgi/doi/10.1101/gad.1371105. unique component of the U7-specific Sm core, in which the spliceosomal SmD1 and SmD2 proteins are replaced by Lsm 10 and Lsm 11 (Pillai et al. 2001, 2003). The site of endonucleolytic attack, which usually occurs after a CA dinucleotide in the histone pre-mRNA sequence, is located 10-11 nucleotides (nt) upstream of the intermolecular U7/HDE RNA duplex (Scharl and Steitz 1994, 1996). In mammalian nuclear extracts, SLBP is not required for in vitro processing of pre-mRNA substrates with strong complementarity to the $5^{\prime}$ end of U7 snRNA (Streit et al. 1993; Dominski et al. 1999).

In addition to the U7 snRNP (Strub et al. 1984; Mowry and Steitz 1987), an unidentified heat-labile factor (HLF) (Gick et al. 1987; Lüscher and Schümperli 1987) is absolutely essential for histone pre-mRNA processing in extracts of mammalian cells. The HLF was described almost 20 years ago (Gick et al. 1987) and is distinct from the U7 snRNP in that it is resistant to micrococcal nuclease and is not depleted by anti-Sm antibodies. It is inactivated by treatment of nuclear extract for $15 \mathrm{~min}$ at $50^{\circ} \mathrm{C}$, while the $\mathrm{U} 7$ snRNP remains stable and active under these conditions (Gick et al. 1987). The HLF is present in small amounts in extracts prepared from G1arrested cells, but is highly enriched in extracts from exponentially growing cells (Lüscher and Schümperli 1987).

We describe purification of the HLF from HeLa cell nuclear extract and show that it is a large complex that shares subunits with the well-characterized CPSF and CstF complexes (Takagaki et al. 1989) involved in the 
cleavage and polyadenylation of the majority of messenger RNAs. Most unexpected was the identification of symplekin as the heat-sensitive component, a protein that has been implicated in nuclear polyadenylation (Takagaki and Manley 2000; Xing et al. 2004) and assigned an essential role in the elongation of poly(A) tails in the cytoplasm (Barnard et al. 2004).

\section{Results}

Fractionation of the HLF reveals polyadenylation components and symplekin

To identify factors required for histone mRNA 3 '-end processing, we used an RNA substrate derived from the mouse histone H4-12 pre-mRNA, whose HDE has excellent complementarity to the $5^{\prime}$ end of U7 snRNA (Fig. 1A) and thus undergoes SLBP-independent cleavage in vitro (Streit et al. 1993). In preliminary experiments, we had used a $\mathrm{Ni}^{2+}$-affinity resin to purify the transcription factor Yin Yang 1 (YY1) (Shi et al. 1991) because it had been shown to activate transcription of histone genes (Eliassen et al. 1998; Last et al. 1999) and has zinc fingers homologous to those of ZFP100 (Dominski et al. 2002). Since YY1 contains 11 consecutive histidines, we incubated crude HeLa cell nuclear extract with the resin under stringent conditions: $400 \mathrm{mM}$ salt and $20 \mathrm{mM}$ imidazole (Fig. 1B). Although subsequent experiments indicated no direct role for YY1 in histone pre-mRNA processing, we discovered that the material eluted from the $\mathrm{Ni}^{2+}$-affinity resin could complement the processing activity of a heat-inactivated extract (data not shown).

To further purify the HLF, the $\mathrm{Ni}^{2+}$-resin eluate was fractionated by ammonium sulfate precipitation (Fig. 1C). While the resulting precipitates alone possessed no ability to process the H4-12 pre-mRNA substrate (data not shown), complementation of a heat-inactivated nuclear extract (Fig. 1D) revealed the highest HLF activity in the $60 \%$ saturated ammonium sulfate fraction (Fig. 1D, lane 5). This activity was completely destroyed by heat treatment after mixing with the nuclear extract (Fig. 1E, lane 4) and almost completely lost by exposure to $50^{\circ} \mathrm{C}$ separate from the extract (Fig. 1E, lane 5). Attempts to further purify the HLF activity on anion- or cation-exchange resins resulted in poor separation from the bulk of the proteins and gradual but significant loss of activity (data not shown).

We therefore used glycerol gradient centrifugation to fractionate the $60 \%$ ammonium sulfate precipitate containing HLF activity. While the majority of proteins sedimented near the top of the gradient (slower than 7.6S) (Fig. 2A), fraction $8(14.7 \mathrm{~S})$ had the greatest ability to restore processing to a heat-inactivated HeLa nuclear extract, followed closely by fraction 7; trace HLF activity was found in fraction 9 (Fig. 2B). Silver staining of these glycerol gradient fractions separated by SDS-PAGE revealed only a few bands whose profile closely mirrored HLF activity (Fig. 2C, bands indicated by dots). These comigrating proteins were selected for analysis by tandem mass spectrometry. After tryptic digestion, LC MS/
A

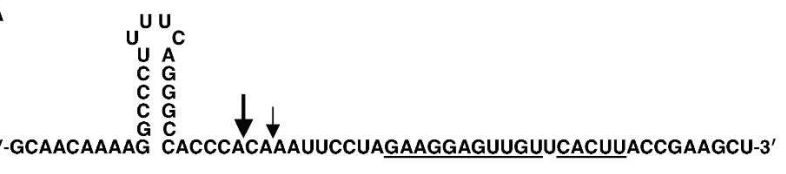

B
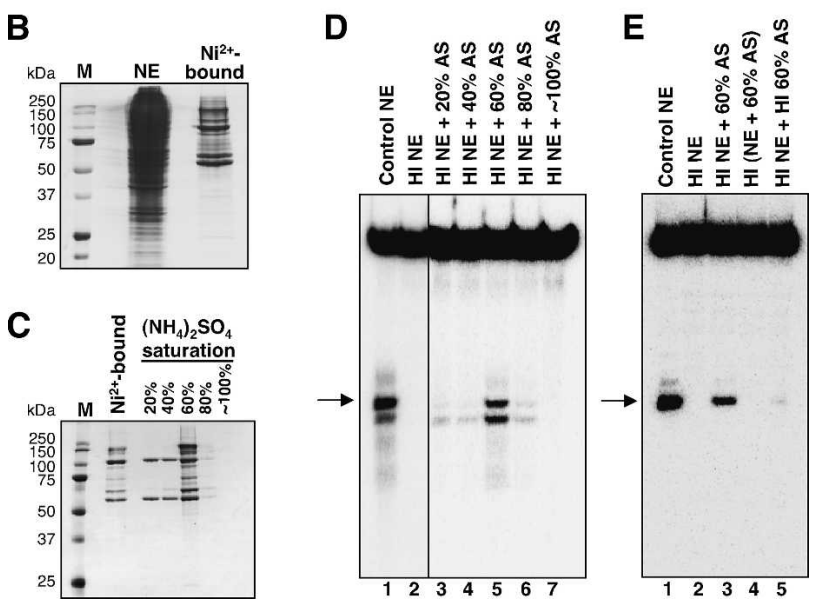

Figure 1. HLF activity is retained on $\mathrm{Ni}^{2+}$-affinity resin. $(A)$ The histone H4-12 pre-mRNA substrate used in the in vitro processing assays. The sequence that is complementary to the $5^{\prime}$-end of U7 snRNA is underlined. Large and small arrows indicate the alternative (major and minor) positions of endonucleolytic scission (Streit et al. 1993). (B) Coomassie brilliant blue-stained SDS-PAGE of the crude nuclear extract (NE) starting material $\left(1 / 250^{\text {th }}\right)$ and of the material eluted from $\mathrm{Ni}^{2+}$-NTA agarose $\left(1 / 50^{\text {th }}\right)$. Lane $M$ shows molecular weight marker proteins. $(C)$ Saturated $\left(\mathrm{NH}_{4}\right)_{2} \mathrm{SO}_{4}$ was added progressively to the material eluted from the $\mathrm{Ni}^{2+}$ resin to achieve the indicated percent saturation values. Precipitated proteins were resuspended and visualized by Coomassie staining after separation on $10 \%$ SDS-PAGE. $(D)$ Complementation of in vitro processing. HeLa nuclear extract (NE) was incubated at $50^{\circ} \mathrm{C}$ for $15 \mathrm{~min}$ to generate heat-inactivated extract $(\mathrm{HI})$, which was used for processing of a uniformly labeled H4-12 pre-mRNA substrate either without supplementation (lane 2) or after addition of the indicated ammonium sulfate (AS) precipitates (lanes 3-7). Lane 1 shows processing in the extract before heat inactivation. The arrow indicates the upstream fragment $(30 \mathrm{nt})$ produced by cleavage at the major site indicated in $A$; additional bands above and below are degradation products of the downstream fragment (36 nt). (E) The $60 \%$ ammonium sulfate fraction containing HLF activity $(60 \% \mathrm{AS})$ is inactivated by heat treatment (15 min at $50^{\circ} \mathrm{C}$ ). In vitro processing using a $5^{\prime}$-end labeled $\mathrm{H} 4-12$ premRNA substrate. (Lane 1) Non-heat-treated extract. (Lane 2) Heat-inactivated extract. (Lane 3) Heat-inactivated extract complemented with the non-heat-treated $60 \%$ AS fraction. (Lane 4) A nontreated extract and the $60 \%$ AS fraction were mixed and incubated together at $50^{\circ} \mathrm{C}$. (Lane 5) The extract and the $60 \%$ AS fraction were heat treated separately, then combined prior to addition of the processing substrate. The arrow indicates the upstream product resulting from cleavage at the major site; the faint band above results from processing at the minor position shown in $A$.

MS identified the polypeptides migrating at $\sim 150,100$, and $75 \mathrm{kDa}$ as subunits of the cleavage and polyadenylation specificity factor: CPSF-160 (three peptide matches), CPSF-100 (10 peptide matches), and CPSF-73 (four 
A

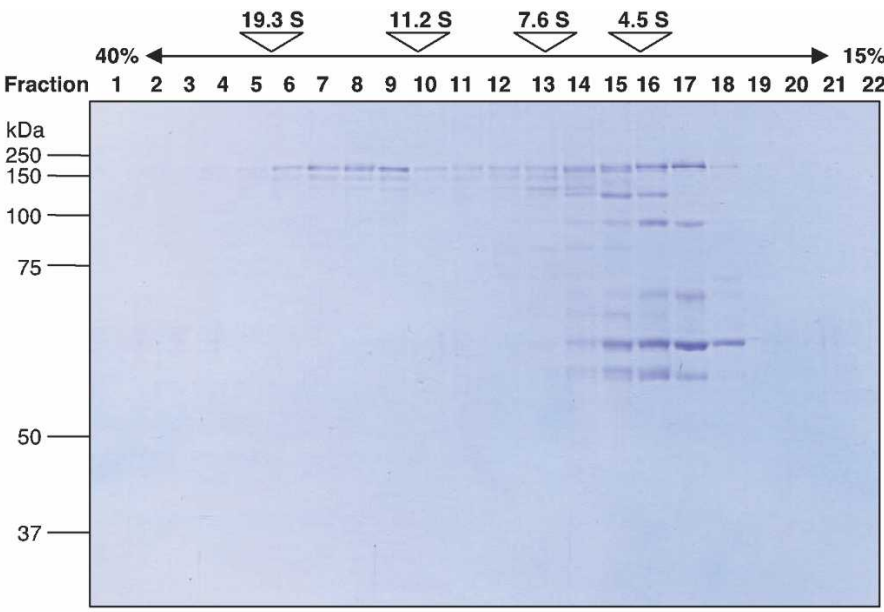

B
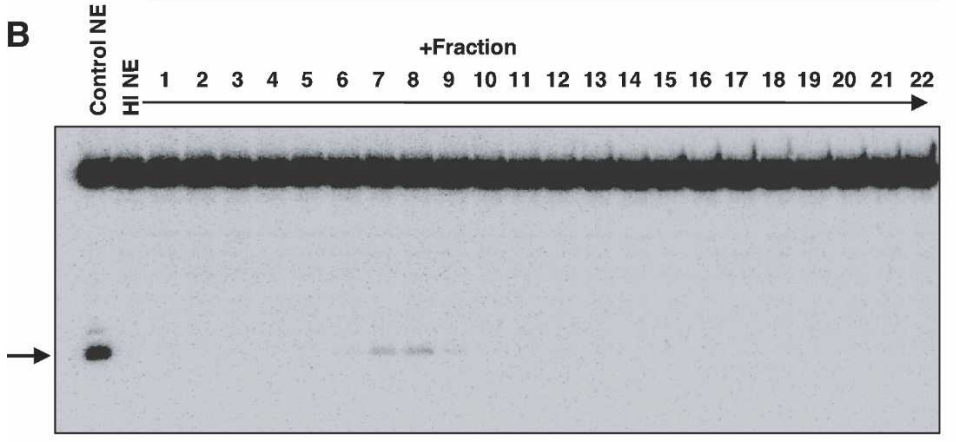

C

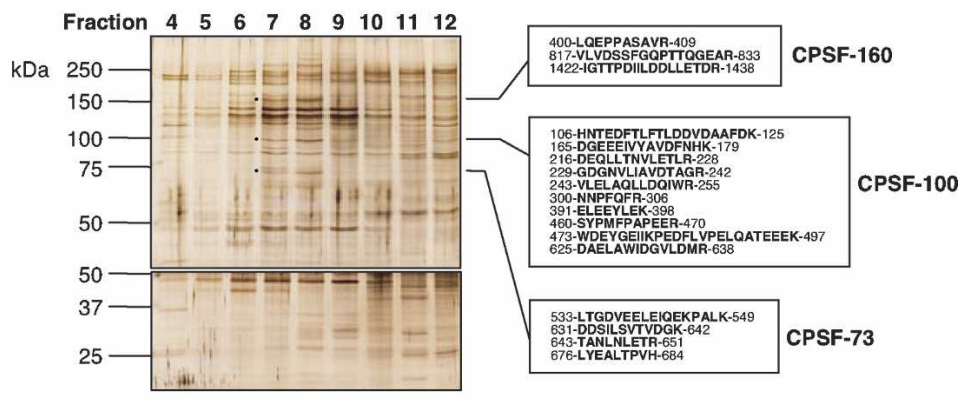

\begin{tabular}{lllllllllllllllllllllll} 
Fraction & 1 & 2 & 3 & 4 & 5 & 6 & 7 & 8 & 9 & 10 & 11 & 12 & 13 & 14 & 15 & 16 & 17 & 18 & 19 & 20 & 21 & 22 \\
\hline & & & & & & & & &
\end{tabular}

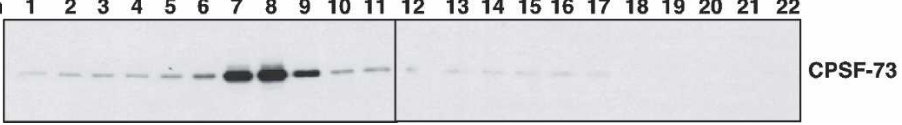

Figure 2. HLF activity sediments at $14.7 \mathrm{~S}$. (A) Protein profile of the $60 \%$ ammonium sulfate precipitate after $15 \%-40 \%$ glycerol gradient fractionation. Proteins were separated by $10 \%$ SDS-PAGE and stained with Coomassie. Above is shown the distribution of size markers in a parallel gradient: porcine thyroglobulin (19.3S, $669 \mathrm{kDa})$, bovine catalase (11.2S, $232 \mathrm{kDa})$, bovine lactate dehydrogenase $(7.6 \mathrm{~S}, 140 \mathrm{kDa})$, and bovine serum albumin $(4.5 \mathrm{~S}, 66 \mathrm{kDa})$. It should be noted that purified CPSF has a sedimentation coefficient of 11.5S (Bienroth et al. 1991; Murthy and Manley 1992), even though the predicted combined molecular weight of its subunits (excluding hFip 1 ) is $357 \mathrm{kDa}$. (B) Complementation of in vitro processing by glycerol gradient fractions. Glycerol gradient fractions shown in $A$ were mixed with heat-inactivated extract and incubated with a $5^{\prime}$-end labeled H4-12 substrate. The arrow indicates the major upstream cleavage product. We calculate (accounting for the dilution in the gradient) that fractions 7,8 , and 9 (14.7S fraction) combined contain slightly more HLF activity than the starting $60 \%$ ammonium sulfate precipitate. This indicates that there is no significant HLF stimulatory activity sedimenting with the bulk of the protein at $\sim 4.5 \mathrm{~S}$ in our gradients. (C) SDS-PAGE (7\% gel, top; $13 \%$ gel, bottom) of the fractions in the vicinity of HLF activity in the glycerol gradient shown in $A$ was followed by silver staining. The boxes show tryptic peptide sequences identified by LC MS/MS analysis for the bands marked with black dots. Numbers indicate the amino acid positions within the sequences of the identified proteins. $(D)$ Western blot analysis of all fractions from the glycerol gradient of $A$ using anti-CPSF-73 antibody. matching peptides), respectively (Fig. 2C). Western blotting revealed a precise match between HLF activity and the distribution of CPSF-73 across all fractions of the gradient (Fig. 2D).

The surprising finding that CPSF-73 (Jenny et al. 1996), CPSF-100 (Jenny et al. 1994), and CPSF-160 (Murthy and Manley 1995) comigrate with HLF activity at 14.7S, similar to the previously reported $\sim 14 \mathrm{~S}$ for the HLF (Gick et al. 1987) versus the $11.5 \mathrm{~S}$ value determined independently by two groups for the purified CPSF complex (Bienroth et al. 1991; Murthy and Manley 1992), prompted us to test for the presence of other components of the cleavage and polyadenylation machinery. Western blot analysis of the same glycerol gradient fractions
(Fig. 3A) revealed that the other two CPSF subunits, CPSF-30 (Barabino et al. 1997) and hFip1 (Kaufmann et al. 2004), also peak in fraction 8, as do two subunits of the cleavage stimulation factor (Takagaki et al. 1990), CstF-77 (Takagaki and Manley 1994), and CstF-64 (Takagaki et al. 1992). The 50-kDa third subunit of CstF (Takagaki and Manley 1992), as well as the subunits of the heterodimeric cleavage factor $\mathrm{I}_{\mathrm{m}}\left(\mathrm{CF} \mathrm{I}_{\mathrm{m}} 72,68,59\right.$, and CF $I_{m}$ 25) (Rüegsegger et al. 1998) and two of the identified subunits of cleavage factor IIA (hClpl and hPcf11) (de Vries et al. 2000) did not comigrate with HLF activity but were detected in lighter fractions (Fig. 3A).

The profile of cleavage factors present in fraction 8 (colored proteins in Fig. 3 B) was remarkably similar to 
A

Fraction

2468810121416182022

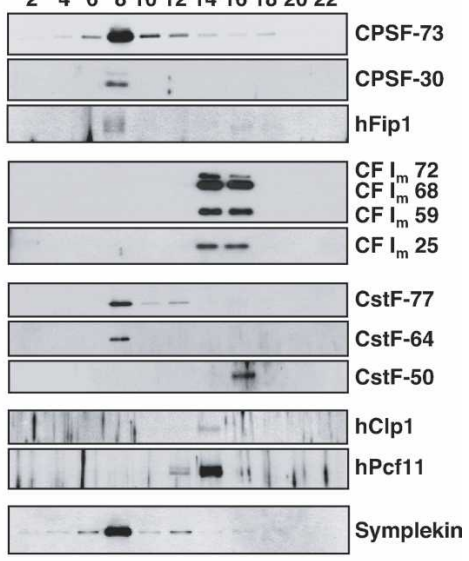

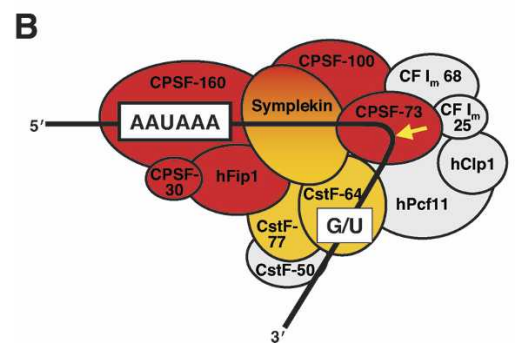

Figure 3. CPSF, CstF subunits, and symplekin cofractionate with HLF activity. (A) Western blots of fractions from a glycerol gradient separating the $60 \%$ ammonium sulfate precipitate, as in Figure 2. Only even-numbered fractions were analyzed for the presence of the proteins listed on the right. HLF activity peaked in fraction 8 (data not shown). (B) Diagram depicting proteins assigned to the cleavage and polyadenylation machinery, excluding poly(A) polymerase (Ryan et al. 2004). It has been previously observed that nuclear PAP does not copurify with either CPSF or CstF (Takagaki et al. 1989, and references therein). Consensus sequences and the site of cleavage (arrow) prior to polyadenylation are shown. HLF proteins concentrated in fraction 8 , as identified by either mass spectrometry (Fig. 2C) or Western blotting $(A)$ are colored red $(\mathrm{CPSF})$ and orange $(\mathrm{CstF})$. Proteins peaking elsewhere in the gradient are colored gray.

that of a large complex immunoprecipitated by Takagaki and Manley (2000) from nuclear extracts using anti-CstF64 antibodies. In the coimmunoprecipitate, they also found symplekin, a protein migrating at $150 \mathrm{kDa}$ that was recently implicated in the cytoplasmic polyadenylation of mRNAs occurring upon maturation of Xenopus oocytes (Barnard et al. 2004). We asked whether symplekin might be a component of the 14.7S HLF complex by Western blotting (Fig. 3A, bottom). It was indeed detected, peaking in fraction 8 .

\section{Heat compromises the integrity and processing} activity of the complex

We reasoned that heat lability of a multimolecular complex could be due either to its dissociation into subcom- plexes or to irreversible denaturation of one or more particular components. To examine the effect of heat on the 14.7S HLF complex, we performed glycerol gradient fractionation of a crude HeLa nuclear extract after exposure to different temperatures for $15 \mathrm{~min}$. As reported by Gick et al. (1987), incubation of our extract at temperatures above $46^{\circ} \mathrm{C}$ abolished processing of the SLBP-independent H4-12 pre-mRNA substrate (Fig. 4A). The glycerol gradient fractions from the nuclear extract treated at the different temperatures were then blotted with antibodies against CPSF-73 and CstF-64, constituents of two different multisubunit complexes (Takagaki et al. 1989) known to be involved in nuclear cleavage and polyadenylation of pre-mRNAs (Fig. 4B,D) as well as against symplekin (Fig. 4C).

The control unheated extract showed major peaks for both CPSF-73 and CstF-64 in fraction 8, where the HLF activity concentrates (as in Fig. 2B; data not shown). Redistribution of these proteins from fraction 8 to lighter fractions in the gradients closely correlated with temperature inactivation of the processing activity (Fig. 4B,D). This argues that CPSF and CstF are components of the same rather than different active complexes that sediment at $14.7 \mathrm{~S}$.
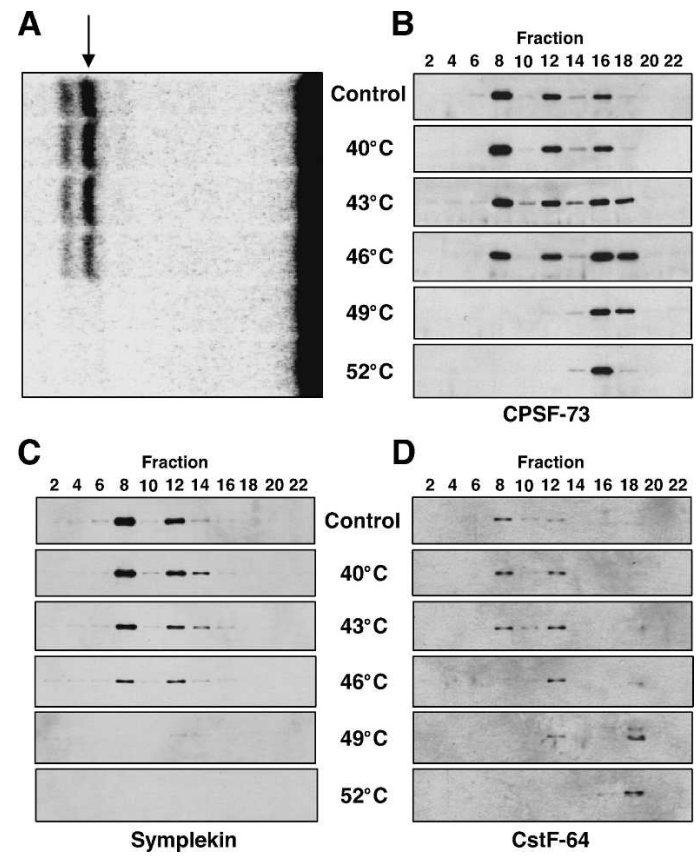

Figure 4. Heat destroys the integrity of the 14.7S HLF complex. $(A)$ In vitro processing of histone pre-mRNA in HeLa nuclear extracts pretreated for $15 \mathrm{~min}$ at the indicated temperatures compared with a non-heat-treated extract (Control). The H4-12 substrate was internally ${ }^{32} \mathrm{P}$-labeled. The arrow indicates the upstream cleavage product. Additional bands above and below are degradation products of the downstream fragment. (B$D)$ The heat-treated nuclear extracts assayed in $A$, as well as a non-heat-treated extract (Control), were fractionated on $15 \%$ $40 \%$ glycerol gradients. Every other fraction was subjected to SDS-PAGE and immunoblotted with antibodies against CPSF73, Symplekin, or CstF-64. 
In contrast, upon heat inactivation and centrifugation of the extract, the signal for symplekin (Fig. 4C) progressively disappeared, becoming completely absent at $49^{\circ} \mathrm{C}$ and higher. Since symplekin was not found at the very bottom of the gradients (in fraction 1; data not shown), we conclude that either it was proteolytically degraded or the epitope recognized by the monoclonal antibody used in the assay becomes altered upon denaturation. Whatever the case, the effect of heat on symplekin, manifested by its disappearance from these Western blots, is not only associated with, but precisely matches the temperature inactivation profile of the nuclear extract.

We attempted depletion with antibodies against CPSF73 and symplekin, but in both cases were unable to deplete HLF activity. In the case of the anti-CPSF-73 antibody, similar observations were made by Dominski et al. (2005); they were able to immunoprecipitate the protein only after boiling the extract in the presence of SDS and subsequent dilution of the detergent. In the case of the anti-symplekin antibody, Barnard et al. (2004) were able to immunodeplete from Xenopus oocyte extract the cytoplasmic polyadenylation activity. We used much higher amounts of the same antibody and still did not achieve immunodepletion of the HLF, which may indicate that the two complexes are quite different, and in the HLF complex, the epitope recognized by the monoclonal anti-symplekin antibody is not accessible.

\section{Symplekin reconstitutes processing in heat-treated extract}

To address which component is responsible for the heat lability of the HLF complex in the processing of histone pre-mRNAs, we performed complementation assays. Each of the cleavage and polyadenylation factor subunits identified in fraction 8 of the glycerol gradient of the $60 \%$ saturated ammonium sulfate precipitate was synthesized from its cloned cDNA by in vitro transcription/ translation (TNT) in rabbit reticulocyte lysate. Symplekin is shown as an example in Figure 5; it is detected only when the TNT was programmed with symplekin cDNA. All eight TNTs were then tested both singly and in multiple combinations for their ability to reconstitute cleavage activity in heat-inactivated extract.

Symplekin was the only protein that restored cleavage of the histone H4-12 pre-mRNA substrate (Fig. 5; data not shown for the proteins that did not complement). Its addition alone to the heat-treated nuclear extract was sufficient. Moreover, addition of in vitro synthesized symplekin to heat-inactivated extract caused the redistribution of CPSF-73 to heavier fractions in the glycerol gradient, coincident with the rescued processing activity (data not shown). Together, these results demonstrate that symplekin is the temperature-sensitive component of the HLF necessary for 3 '-end maturation of histone messages. It is absolutely required for this processing event, but most likely acts only in concert with the other polypeptides, such as CPSF-73, with which it stably associates.

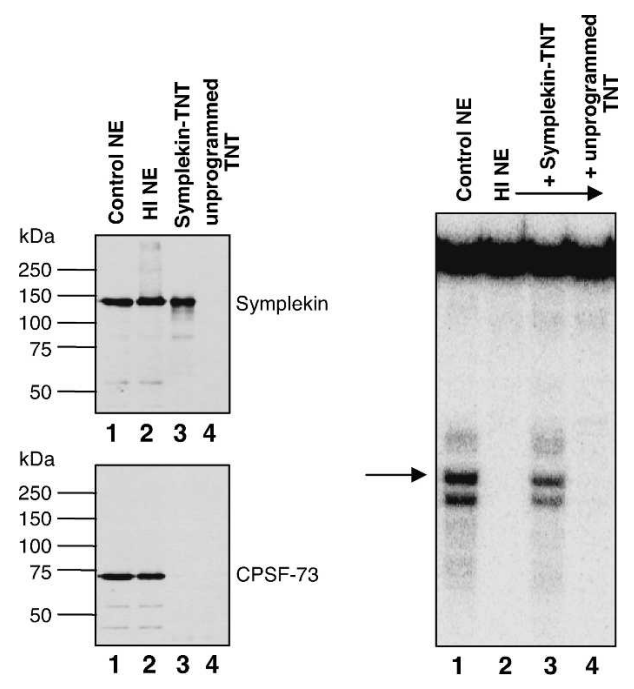

Figure 5. In vitro-translated symplekin restores processing activity in heat-inactivated extract. (Left) Western blots analyzing the presence of symplekin (top) or CPSF-73 (bottom) in equal volumes of non-heat-treated nuclear extract (lane 1), heat-inactivated extract (lane 2), symplekin cDNA-programmed TNT reaction (lane 3), or an unprogrammed TNT reaction (lane 4). Note that the symplekin band does not disappear immediately after heat treatment, suggesting that its heat-induced inactivation precedes its degradation during the lengthy centrifugation in the glycerol gradients. The right panel shows in vitro processing of an internally ${ }^{32} \mathrm{P}$-labeled H4-12 pre-mRNA substrate in control non-heat-inactivated nuclear extract (lane 1), heatinactivated (HI) extract (lane 2), HI extract supplemented with a transcription/translation reaction (TNT) programmed with symplekin cDNA (lane 3), or HI extract supplemented with an unprogrammed TNT reaction (lane 4).

\section{Discussion}

We have discovered that symplekin is the heat-labile component of a multimolecular complex required for histone mRNA 3 '-end formation. The HLF assembly also contains many, but not all factors previously assigned to the nuclear cleavage and polyadenylation machinery that fashions the polyadenylated ends of most mRNAs. The eight proteins have a combined predicted molecular weight of $694 \mathrm{kDa}$, consistent with a single complex sedimenting at $14.7 \mathrm{~S}$; this suggests that we have identified the majority, if not all constituents of the HLF complex (Fig. 6). The functional integrity of the complex appears to depend on symplekin, since heatinduced disassembly and loss of activity are coupled and addition of in vitro-synthesized symplekin rescues histone pre-mRNA processing in a heat-inactivated extract.

Symplekin was initially identified as a component of tight junctions in polar epithelial cells and Sertoli cells and is also present in the nuclei of all types of cultured mammalian cells and tissues examined (Keon et al. 1996). Takagaki and Manley (2000) first suggested its involvement (perhaps in a scaffolding role) in mRNA 3'end formation by showing interactions with CstF-77 and CstF-64, as well as with CPSF-160, CPSF-100, and CPSF73 (Takagaki and Manley 2000; Hofmann et al. 2002). 


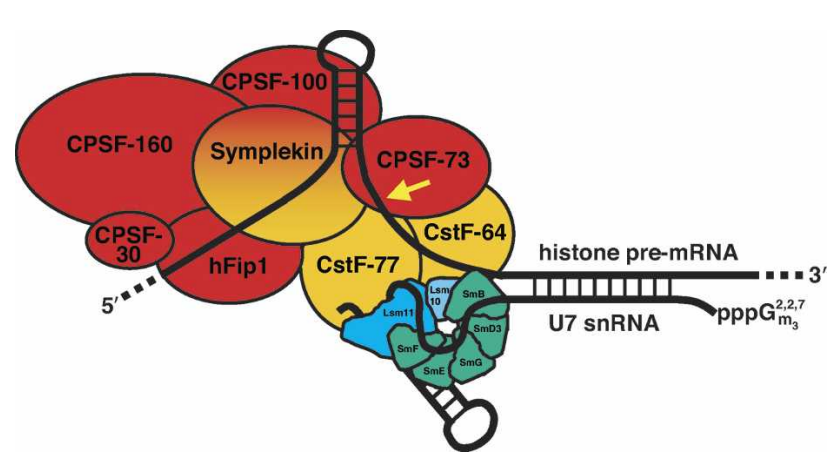

Figure 6. Model for histone pre-mRNA processing. Components of the HLF identified in this study are colored red and orange. The U7 snRNA is depicted base pairing with the histone pre-mRNA downstream element. We propose that the U7 snRNP orients the histone pre-mRNA for cleavage (arrow) by CPSF-73 through contacts between its Sm proteins and the CstF subunits in HLF (see text). Proteins of the Sm ring that are shared with spliceosomal snRNPs are shown in green; the U7specific Lsm10 and Lsm11 proteins (Pillai et al. 2001, 2003) are shown in shades of blue.

Importantly, symplekin has been shown to be required for poly(A) tail elongation of mRNAs containing a cytoplasmic polyadenylation element (CPE), a regulated process that occurs in the cytoplasm during oocyte maturation (Barnard et al. 2004), as well as during cell cycle progression (Groisman et al. 2002) and synaptic stimulation of neurons (Wu et al. 1998; Huang et al. 2002). The data of Barnard et al. (2004) clearly demonstrate that cytoplasmic symplekin associates with CPSF, as well as with $\mathrm{CPEB}$, an RNA-binding protein that recognizes the CPE.

What are the roles of the various polyadenylation factors we have identified as HLF components in histone pre-mRNA processing? The major functions of CPSF and CstF, respectively, in recognizing the upstream AAUAAA and downstream G/U-rich region that flank the cleavage site in polyadenylation substrates (Murthy and Manley 1995; Takagaki and Manley 1997), seem irrelevant, since these features are absent in histone premRNAs. The crude nuclear extracts from which we have isolated the HLF are, in fact, markedly reduced in their activity to cleave polyadenylation substrates /data not shown). Instead, the CPSF and CstF components may serve to forge a link between the U7 snRNP and the endonuclease that cleaves downstream of the CA dinucleotide in the pre-mRNA substrate, producing the 3'-OH terminus (Scharl and Steitz 1994) of the mature histone mRNA.

CPSF-73 seems most likely to be the endonuclease that creates the $3^{\prime}$ ends of histone mRNAs since it is a member of the metallo- $\beta$-lactamase family of $\mathrm{Zn}^{2+}$-dependent hydrolytic enzymes (Callebaut et al. 2002). This assignment is strongly supported by the studies of Dominski et al. (2005), who have recently characterized a U7 snRNP-dependent cross-link between the cleavage site of a histone pre-mRNA substrate and CPSF-73. In the case of polyadenylated mRNAs, Ryan et al. (2004) have reported both protein-RNA cross-linking data and mutational analyses that implicate CPSF-73 as the catalytic subunit that executes the cleavage step prior to polyadenylation. Moreover, the same specificity-creation of a $3^{\prime}$-OH downstream of CA-is seen for cleavage/polyadenylation substrates (Sheets et al. 1987) as for histone premRNAs. Our identification of all the subunits of CPSF as components of the HLF assembly provides additional support for the conclusion that CPSF-73 is the 3 '-endonuclease in histone pre-mRNA processing.

It is interesting that CstF-50 is missing from the HLF complex. CstF-50 exhibits extensive homology to mammalian G-protein $\beta$-subunits (Takagaki and Manley 1992), including seven WD40 domains, which X-ray analysis shows form toroidal structures (Wall et al. 1995; Lambright et al. 1996; Sondek et al. 1996). This architecture is reminiscent of the heteroheptameric ring of the Sm protein core (Kambach et al. 1999; Raker et al. 1999). We hypothesize that the U7 snRNP may replace CstF-50 in the assembled processing complex, interacting with the other CstF subunits via its Sm protein ring (Fig. 6). In this scenario, symplekin would act as a scaffold protein, similar to its proposed role in the cytoplasmic polyadenylation complex (Barnard et al. 2004). By making documented contacts with three of the five subunits of CPSF (Hofmann et al. 2002) and the remaining two subunits of CstF (Takagaki and Manley 2000), symplekin would bring the endonuclease (CPSF-73) and the U7 snRNP together into a single assembly. Since the higher-order complex containing HLF and the U7 snRNP would be extremely large, it is possible that it represents the elusive molecular measuring device (Scharl and Steitz 1994, 1996) that spans from the duplex formed between U7 and the HDE to the site of cleavage $11 \mathrm{nt}$ upstream in the histone pre-mRNA.

Our findings rationalize previous observations that symplekin and other polyadenylation factors are enriched in or intimately associated with Cajal bodies (Schul et al. 1996, 1999; Gall et al. 1999; Hofmann et al. 2002). Cajal bodies (formerly called coiled bodies) are highly conserved nuclear organelles that are particularly prominent in rapidly cycling cells. The U7 snRNP has been shown to preferentially reside in Cajal bodies both in Xenopus oocytes (where they are also named spheres or C snurposomes) (Wu and Gall 1993) and in mammalian cells (Frey and Matera 1995). Snurposomes also contain SLBP (Abbott et al. 1999). The tight association of Cajal bodies with histone gene loci was noted long ago for the lampbrush chromosomes of newt (Gall et al. 1981) and of Xenopus (Callan et al. 1991). In mammalian cells, Cajal bodies preferentially localize at both histone loci and gene arrays encoding U1 and U2 snRNAs (Frey and Matera 1995). Our characterization of the proteins present in the HLF complex (see Fig. 6) suggests that Cajal bodies contain the complete set of processing components for histone mRNA 3'- end maturation, neatly packaged for delivery to chromosomal sites of histone gene transcription.

The HLF required for 3 '-end processing of histone premRNAs has been reported to be cell-cycle regulated with 
its level low in G1-arrested cells and high during exponential growth (Lüscher and Schümperli 1987). So far, the only component of the HLF complex we have characterized that has been reported to fluctuate during the cell cycle is CstF-64 (Martincic et al. 1998). It or any other untested component could contribute to the cell cycle-dependent variation in HLF activity. On the other hand, Marzluff and Duronio (2002) have argued that the cell cycle regulation of SLBP could account for the differing levels of histone 3 '-end processing during the cell cycle; conflicting data have been reported regarding the heat sensitivity of SLBP (Melin et al. 1992; Dominski et al. 1999).

Our discovery that symplekin and certain other polyadenylation factors participate in histone mRNA 3 '-end maturation raises the question of how many cellular roles these versatile proteins play. They appear to exchange molecular partners depending on their cellular location-nucleoplasm, cytoplasm, or Cajal body-associated. For instance, in the nucleoplasm, the poly(A) polymerase (PAP), which does not copurify with CPSF or CstF (Takagaki et al. 1989), is engaged; in the cytoplasm, GLD-2 is the polymerase recruited for extension of poly(A) tails (Barnard et al. 2004); when Cajal body-associated, no nucleotide addition occurs after cleavage. It will be interesting to analyze the detailed intermolecular contacts in these various $3^{\prime}$-end forming machines and to learn whether some of the interactions are mutually exclusive; for example, does symplekin or the U7 snRNP displace CstF-50 from the other two CstF subunits in the histone system? Are all of the HLF components pictured in Figure 6 essential for activity? Have all necessary subunits been identified? The finding that shared factors contribute to the nuclear processing of mRNAs with and without $3^{\prime}$ poly(A) and to the regulated elongation of poly(A) tails in the cytoplasm points to a common evolutionary origin for the $3^{\prime}$-end formation apparatus in all eukaryotic cells.

\section{Materials and methods}

\section{Preparation of HeLa nuclear extract}

A procedure for the preparation of Drosophila $\mathrm{K}_{\mathrm{c}}$ cell nuclear extract (Price et al. 1987) was followed, with modifications. HeLa cells were washed with 5-10 pellet volumes of ice-cold PBS. The collected cells were resuspended in 5 pellet volumes of buffer A (10 mM HEPES at pH 7.9, $10 \mathrm{mM} \mathrm{KCl,} 1.5 \mathrm{mM} \mathrm{MgCl}_{2}$, $1 \mathrm{mM}$ DTT, $0.1 \%$ saturated PMSF) and incubated on ice for 10 min. After lysing the the cells with 10 strokes in a Dounce homogenizer (Kontes, type B tight-fitting pestle), the nuclei were pelleted by centrifugation for $10 \mathrm{~min}$ at $2500 \mathrm{rpm}$ in a Sorvall SS34 rotor at $4^{\circ} \mathrm{C}$. The nuclear pellet received $1.6 \mathrm{vol}$ of buffer $\mathrm{A}$, and the nuclei were resuspended by 20 strokes in the Dounce homogenizer. To the suspension (transferred into a centrifuge tube) was added 0.1 vol of $4 \mathrm{M}\left(\mathrm{NH}_{4}\right)_{2} \mathrm{SO}_{4}$, and the mixture was incubated with gentle mixing at $4^{\circ} \mathrm{C}$ for $30 \mathrm{~min}$. After centrifugation at $18,000 \mathrm{rpm}$ in a Sorvall SS34 rotor for $60 \mathrm{~min}$ at $4^{\circ} \mathrm{C}$, the clear supernatant was transferred to a new tube, and $0.3 \mathrm{~g}$ of solid $\left(\mathrm{NH}_{4}\right)_{2} \mathrm{SO}_{4}$ was added per milliliter of extract. The suspension was incubated for $20 \mathrm{~min}$ at $4^{\circ} \mathrm{C}$ with end-to-end rotation. After centrifugation at 12,000 rpm in a Sorvall SS34 rotor for $10 \mathrm{~min}$ at $4^{\circ} \mathrm{C}$, the pellet was resuspended in $1.5-2$ starting nuclear volumes of buffer $\mathrm{A}$ and dialyzed against buffer $\mathrm{D}$ (20\% glycerol, $20 \mathrm{mM}$ HEPES at pH 7.9, $90 \mathrm{mM} \mathrm{KCl}, 10 \mathrm{mM}$ $\left(\mathrm{NH}_{4}\right)_{2} \mathrm{SO}_{4}, 0.2 \mathrm{mM}$ EDTA, $1 \mathrm{mM}$ DTT, $0.1 \%$ saturated PMSF). The crude nuclear extract was stored at $-80^{\circ} \mathrm{C}$.

\section{Purification of the HLF}

HeLa nuclear extract $(2.5 \mathrm{~mL})$ was dialyzed against $500 \mathrm{~mL}$ dialysis buffer (20\% glycerol, $50 \mathrm{mM}$ HEPES at pH 7.9, $400 \mathrm{mM}$ $\mathrm{KCl}, 20 \mathrm{mM}$ imidazole, $0.1 \%$ saturated PMSF) for $1 \mathrm{~h}$ at $4^{\circ} \mathrm{C}$. The extract was diluted to $5 \mathrm{~mL}$ with dialysis buffer and then added to a centrifuge tube containing $1 \mathrm{~mL} \mathrm{Ni}^{2+}$-nitrilotriacetic acid $\left(\mathrm{Ni}^{2+}{ }_{-} \mathrm{NTA}\right)$ metal-affinity resin (QIAGEN) that had been equilibrated with dialysis buffer. After incubation for $1 \mathrm{~h}$ at $4^{\circ} \mathrm{C}$ with end-to-end rotation, the resin was collected by centrifugation and washed three times with $10 \mathrm{~mL}$ of dialysis buffer. Bound material was eluted with $2 \mathrm{~mL}$ of elution buffer $(20 \%$ glycerol, $50 \mathrm{mM}$ HEPES at $\mathrm{pH}$ 7.9, $400 \mathrm{mM} \mathrm{KCl}, 500 \mathrm{mM}$ imidazole, $0.1 \%$ saturated PMSF).

Saturated $\left(\mathrm{NH}_{4}\right)_{2} \mathrm{SO}_{4}$ solution was added to the eluate to sequentially achieve the indicated saturation percentages. After each addition, the sample was thoroughly and carefully mixed, incubated on ice for $15 \mathrm{~min}$ and then centrifuged at $13,400 \times \mathrm{g}$ for $10 \mathrm{~min}$ at $4^{\circ} \mathrm{C}$. The pellet after each spin was dissolved in 0.5 $\mathrm{mL}$ of $20 \%$ glycerol, $50 \mathrm{mM}$ HEPES (pH 7.9), 1 mM DTT, $0.1 \%$ saturated PMSF, stored at $-80^{\circ} \mathrm{C}$, and used for complementation of in vitro processing reactions. Glycerol gradients $(15 \%-40 \%$, $10 \mathrm{~mL}$ ) were prepared in gradient buffer (50 mM HEPES at $\mathrm{pH}$ 7.9, $50 \mathrm{mM}\left(\mathrm{NH}_{4}\right)_{2} \mathrm{SO}_{4}, 1 \mathrm{mM} \mathrm{DTT}, 0.1 \%$ saturated PMSF). Either $250 \mu \mathrm{L}$ of the dissolved $60 \%$ ammonium sulfate precipitate or $62.5 \mu \mathrm{L}$ crude nuclear extract were diluted to $1 \mathrm{~mL}$ with gradient buffer prior to loading on the gradient. Centrifugation was for $35.5 \mathrm{~h}$ at $36,000 \mathrm{rpm}$ in a SW 41 Ti rotor. Fractions $(0.5$ $\mathrm{mL}$ ) were collected from the bottom of the gradients, stored at $-80^{\circ} \mathrm{C}$, and used for complementation of processing reactions and for SDS-PAGE and Western blotting.

\section{Protein identification}

In-gel trypsin digestion of Coomassie-stained gel pieces containing individual bands that comigrated with activity and LC MS/ MS analysis of the resulting peptides were performed by the staff of W.M. Keck Foundation Biotechnology Resource Laboratory at Yale University. Following the in-gel trypsin digestion, the samples were separated on a 100- $\mu \mathrm{m}$ I.D. Atlantis C18 column (Waters). The MS/MS spectra were searched using the Mascot distiller (to locate and combine MS/MS spectra) and the Mascot database search algorithm.

\section{RNA substrates and in vitro processing}

The H4-12 histone pre-mRNA substrate was synthesized by T7 transcription. For internally labeled RNA, transcription was in the presence of GpppG cap analog and $\left[\alpha-{ }^{32} \mathrm{P}\right] \mathrm{UTP} ; 5^{\prime}$-end labeled RNA was generated using T4 polynucleotide kinase and $\left[\gamma^{-}{ }^{32} \mathrm{P}\right]$ ATP from dephosphorylated $\mathrm{H} 4-12$ pre-mRNA transcripts. Labeled substrates were purified on denaturing polyacrylamide gels prior to addition to in vitro processing reactions (final volume $20 \mu \mathrm{L}$ ) containing $20 \% \mathrm{HeLa}$ nuclear extract, 10 mM EDTA, $4 \mu \mathrm{g}$ total yeast RNA, and $1-5 \mathrm{fmol}{ }^{32} \mathrm{P}$-labeled substrate. Heat inactivation of the extracts was for $15 \mathrm{~min}$ at $50^{\circ} \mathrm{C}$ (unless indicated otherwise) prior to assembly of the reaction. For complementation assays, the processing reactions were supplemented with $5 \mu \mathrm{L}$ of purified HLF fractions or $3 \mu \mathrm{L}$ in vitro transcription/translation (TNT) reaction. In vitro pro- 
cessing was for $2 \mathrm{~h}$ at $30^{\circ} \mathrm{C}$. After Proteinase $\mathrm{K}$ digestion and precipitation with ethanol, RNAs were subjected to electrophoresis in $15 \%$ polyacrylamide gels in the presence of $8 \mathrm{M}$ urea.

\section{Antibodies and Western blotting}

Monoclonal anti-symplekin antibody (raised against a peptide encompassing amino acids 914-1080) was from BD Biosciences. Rabbit polyclonal affinity-purified antibodies against CPSF-73, CstF-77, and CstF-50 were generous gifts of David Bentley (University of Colorado, Aurora). Rabbit sera against CPSF-30, hFip1, hClp1, CF $I_{m} 68, C F I_{m} 25$, and hPcf11 were generous gifts of Walter Keller (University of Basel, Basel, Switzerland). Monoclonal anti-CstF-64 antibody was from Clinton MacDonald (Texas Tech University, Lubbock). All Western blots were performed using standard procedures, except in the case of the anti-CstF-64 blot, where Tween 20 was omitted from all buffers.

\section{In vitro translation}

Plasmids containing verified full-length cDNA sequences downstream of an SP6 promoter for human CPSF-160, CPSF-73, CPSF-30, hFip1, symplekin, and CstF-64, as well as for mouse CPSF-100 and CstF-77, were obtained from Open Biosystems. In vitro protein synthesis was performed using the TNT SP6 Quick coupled transcription/translation rabbit reticulocyte system (Promega). The efficient translation of each protein was confirmed by labeling with $\left[{ }^{35} \mathrm{~S}\right]$ methionine in a parallel reaction.

\section{Acknowledgments}

We are extremely grateful to D. Bentley, W. Keller, and C. MacDonald for antibodies and to R. Samstein for assistance in preparing nuclear extract. We thank W. Marzluff for sharing unpublished results; K. Tycowski, N. Conrad, S. Mili, and S. Vasudevan for critical reading of the manuscript; and A. Miccinello for secretarial help. This work was supported by National Institutes of Health grant GM26154 to J.A.S., who is an investigator of the Howard Hughes Medical Institute.

\section{References}

Abbott, J., Marzluff, W.F., and Gall, J.G. 1999. The stem-loop binding protein (SLBP1) is present in coiled bodies of the Xenopus germinal vesicle. Mol. Biol. Cell 10: 487-499.

Barabino, S.M., Hübner, W., Jenny, A., Minvielle-Sebastia, L., and Keller, W. 1997. The $30-\mathrm{kD}$ subunit of mammalian cleavage and polyadenylation specificity factor and its yeast homolog are RNA-binding zinc finger proteins. Genes \& Dev. 11: 1703-1716.

Barnard, D.C., Ryan, K., Manley, J.L., and Richter, J.D. 2004. Symplekin and xGLD-2 are required for CPEB-mediated cytoplasmic polyadenylation. Cell 119: 641-651.

Bienroth, S., Wahle, E., Suter-Crazzolara, C., and Keller, W. 1991. Purification of the cleavage and polyadenylation factor involved in the 3 '-processing of messenger RNA precursors. J. Biol. Chem. 266: 19768-19776.

Birchmeier, C., Schümperli, D., Sconzo, G., and Birnstiel, M.L. 1984. 3' editing of mRNAs: Sequence requirements and involvement of a 60-nucleotide RNA in maturation of histone mRNA precursors. Proc. Natl. Acad. Sci. 81: 1057-1061.

Bond, U.M., Yario, T.A., and Steitz, J.A. 1991. Multiple processing-defective mutations in a mammalian histone pre-mRNA are suppressed by compensatory changes in U7 RNA both in vivo and in vitro. Genes \& Dev. 5: 1709-1722.

Callan, H.G., Gall, J.G., and Murphy, C. 1991. Histone genes are located at the sphere loci of Xenopus lampbrush chromosomes. Chromosoma 101: 245-251.

Callebaut, I., Moshous, D., Mornon, J.P., and de Villartay, J.P. 2002. Metallo- $\beta$-lactamase fold within nucleic acids processing enzymes: The $\beta$-CASP family. Nucleic Acids Res. 30: 3592-3601.

de Vries, H., Rüegsegger, U., Hübner, W., Friedlein, A., Langen, H., and Keller, W. 2000. Human pre-mRNA cleavage factor $\mathrm{II}_{\mathrm{m}}$ contains homologs of yeast proteins and bridges two other cleavage factors. EMBO T. 19: 5895-5904.

Dominski, Z., Zheng, L.X., Sanchez, R., and Marzluff, W.F. 1999. Stem-loop binding protein facilitates $3^{\prime}$-end formation by stabilizing U7 snRNP binding to histone pre-mRNA. Mol. Cell. Biol. 19: 3561-3570.

Dominski, Z., Erkmann, J.A., Yang, X., Sanchez, R., and Marzluff, W.F. 2002. A novel zinc finger protein is associated with U7 snRNP and interacts with the stem-loop binding protein in the histone pre-mRNP to stimulate 3 '-end processing. Genes \& Dev. 16: 58-71.

Dominski, Z., Yang, X., and Marzluff, W.F. 2005. The polyadenylation factor CPSF-73 is involved in histone pre-mRNA processing. Cell (in press).

Eliassen, K.A., Baldwin, A., Sikorski, E.M., and Hurt, M.M. 1998. Role for a YY1-binding element in replication-dependent mouse histone gene expression. Mol. Cell. Biol. 18: 7106-7118.

Frey, M.R. and Matera, A.G. 1995. Coiled bodies contain U7 small nuclear RNA and associate with specific DNA sequences in interphase human cells. Proc. Natl. Acad. Sci. 92: 5915-5919.

Gall, J.G., Stephenson, E.C., Erba, H.P., Diaz, M.O., and Barsacchi-Pilone, G. 1981. Histone genes are located at the sphere loci of newt lampbrush chromosomes. Chromosoma 84: 159-171.

Gall, J.G., Bellini, M., Wu, Z., and Murphy, C. 1999. Assembly of the nuclear transcription and processing machinery: Cajal bodies (coiled bodies) and transcriptosomes. Mol. Biol. Cell 10: 4385-4402.

Gick, O., Krämer, A., Keller, W., and Birnstiel, M.L. 1986. Generation of histone mRNA 3' ends by endonucleolytic cleavage of the pre-mRNA in a snRNP-dependent in vitro reaction. EMBO I. 5: 1319-1326.

Gick, O., Krämer, A., Vasserot, A., and Birnstiel, M.L. 1987. Heat-labile regulatory factor is required for $3^{\prime}$ processing of histone precursor mRNAs. Proc. Natl. Acad. Sci. 84: 89378940.

Groisman, I., Jung, M.Y., Sarkissian, M., Cao, Q., and Richter, J.D. 2002. Translational control of the embryonic cell cycle. Cell 109: 473-483.

Hofmann, I., Schnölzer, M., Kaufmann, I., and Franke, W.W. 2002. Symplekin, a constitutive protein of karyo- and cytoplasmic particles involved in mRNA biogenesis in Xenopus laevis oocytes. Mol. Biol. Cell 13: 1665-1676.

Huang, Y.S., Jung, M.Y., Sarkissian, M., and Richter, J.D. 2002. $\mathrm{N}$-methyl-D-aspartate receptor signaling results in Aurora kinase-catalyzed CPEB phosphorylation and $\alpha$ CaMKII mRNA polyadenylation at synapses. EMBO J. 21: 2139-2148.

Jenny, A., Hauri, H.P., and Keller, W. 1994. Characterization of cleavage and polyadenylation specificity factor and cloning of its 100-kilodalton subunit. Mol. Cell. Biol. 14: 8183-8190.

Jenny, A., Minvielle-Sebastia, L., Preker, P.J., and Keller, W. 1996. Sequence similarity between the 73 -kilodalton protein of mammalian CPSF and a subunit of yeast polyadenylation factor I. Science 274: 1514-1517. 
Kambach, C., Walke, S., Young, R., Avis, J.M., de la Fortelle, E., Raker, V.A., Lührmann, R., Li, J., and Nagai, K. 1999. Crystal structures of two Sm protein complexes and their implications for the assembly of the spliceosomal snRNPs. Cell 96: $375-387$.

Kaufmann, I., Martin, G., Friedlein, A., Langen, H., and Keller, W. 2004. Human Fip1 is a subunit of CPSF that binds to U-rich RNA elements and stimulates poly(A) polymerase. EMBO T. 23: 616-626.

Keon, B.H., Schäfer, S., Kuhn, C., Grund, C., and Franke, W.W. 1996. Symplekin, a novel type of tight junction plaque protein. J. Cell Biol. 134: 1003-1018.

Krieg, P.A. and Melton, D.A. 1984. Formation of the 3' end of histone mRNA by post-transcriptional processing. Nature 308: 203-206.

Lambright, D.G., Sondek, J., Bohm, A., Skiba, N.P., Hamm, H.E., and Sigler, P.B. 1996. The $2.0 \AA$ crystal structure of a heterotrimeric G protein. Nature 379: 311-319.

Last, T.J., van Wijnen, A.J., Birnbaum, M.J., Stein, G.S., and Stein, J.L. 1999. Multiple interactions of the transcription factor YY1 with human histone $\mathrm{H} 4$ gene regulatory elements. J. Cell. Biochem. 72: 507-516.

Lüscher, B. and Schümperli, D. 1987. RNA 3' processing regulates histone mRNA levels in a mammalian cell cycle mutant. A processing factor becomes limiting in G1-arrested cells. EMBO J. 6: 1721-1726.

Martincic, K., Campbell, R., Edwalds-Gilbert, G., Souan, L., Lotze, M.T., and Milcarek, C. 1998. Increase in the $64-\mathrm{kDa}$ subunit of the polyadenylation/cleavage stimulatory factor during the $\mathrm{G}_{0}$ to $\mathrm{S}$ phase transition. Proc. Natl. Acad. Sci. 95: 11095-11100.

Marzluff, W.F. and Duronio, R.J. 2002. Histone mRNA expression: Multiple levels of cell cycle regulation and important developmental consequences. Curr. Opin. Cell Biol. 14: 692-699.

Melin, L., Soldati, D., Mital, R., Streit, A., and Schümperli, D. 1992. Biochemical demonstration of complex formation of histone pre-mRNA with U7 small nuclear ribonucleoprotein and hairpin binding factors. EMBO J. 11: 691-697.

Mowry, K.L. and Steitz, J.A. 1987. Identification of the human U7 snRNP as one of several factors involved in the $3^{\prime}$ end maturation of histone premessenger RNA's. Science 238: 1682-1687.

Murthy, K.G. and Manley, J.L. 1992. Characterization of the multisubunit cleavage-polyadenylation specificity factor from calf thymus. J. Biol. Chem. 267: 14804-14811.

- 1995. The 160-kD subunit of human cleavage-polyadenylation specificity factor coordinates pre-mRNA $3^{\prime}$-end formation. Genes \& Dev. 9: 2672-2683.

Pillai, R.S., Will, C.L., Lührmann, R., Schümperli, D., and Müller, B. 2001. Purified U7 snRNPs lack the Sm proteins D1 and D2 but contain Lsm10, a new 14 kDa Sm D1-like protein. $E M B O$ J. 20: 5470-5479.

Pillai, R.S., Grimmler, M., Meister, G., Will, C.L., Lührmann, R., Fischer, U., and Schümperli, D. 2003. Unique Sm core structure of U7 snRNPs: Assembly by a specialized SMN complex and the role of a new component, Lsm11, in histone RNA processing. Genes \& Dev. 17: 23212333.

Price, D.H., Sluder, A.E., and Greenleaf, A.L. 1987. Fractionation of transcription factors for RNA polymerase II from Drosophila $\mathrm{K}_{\mathrm{c}}$ cell nuclear extracts. J. Biol. Chem. 262: 3244-3255.

Raker, V.A., Hartmuth, K., Kastner, B., and Lührmann, R. 1999. Spliceosomal U snRNP core assembly: Sm proteins assemble onto an Sm site RNA nonanucleotide in a specific and ther- modynamically stable manner. Mol. Cell. Biol. 19: 65546565.

Rüegsegger, U., Blank, D., and Keller, W. 1998. Human premRNA cleavage factor $\mathrm{I}_{\mathrm{m}}$ is related to spliceosomal SR proteins and can be reconstituted in vitro from recombinant subunits. Mol. Cell 1: 243-253.

Ryan, K., Calvo, O., and Manley, J.L. 2004. Evidence that polyadenylation factor CPSF-73 is the mRNA 3' processing endonuclease. RNA 10: 565-573.

Scharl, E.C. and Steitz, J.A. 1994. The site of 3' end formation of histone messenger RNA is a fixed distance from the downstream element recognized by the U7 snRNP. EMBO $J$. 13: $2432-2440$.

. 1996. Length suppression in histone messenger RNA 3 '-end maturation: Processing defects of insertion mutant premessenger RNAs can be compensated by insertions into the U7 small nuclear RNA. Proc. Natl. Acad. Sci. 93: 1465914664.

Schaufele, F., Gilmartin, G.M., Bannwarth, W., and Birnstiel, M.L. 1986. Compensatory mutations suggest that base-pairing with a small nuclear RNA is required to form the $3^{\prime}$ end of H3 messenger RNA. Nature 323: 777-781.

Schul, W., Groenhout, B., Koberna, K., Takagaki, Y., Jenny, A., Manders, E.M., Raska, I., van Driel, R., and de Jong, L. 1996. The RNA 3' cleavage factors CstF $64 \mathrm{kDa}$ and CPSF $100 \mathrm{kDa}$ are concentrated in nuclear domains closely associated with coiled bodies and newly synthesized RNA. EMBO $I$. 15: 2883-2892.

Schul, W., van Der Kraan, I., Matera, A.G., van Driel, R., and de Jong, L. 1999. Nuclear domains enriched in RNA 3'-processing factors associate with coiled bodies and histone genes in a cell cycle-dependent manner. Mol. Biol. Cell 10:38153824.

Sheets, M.D., Stephenson, P., and Wickens, M.P. 1987. Products of in vitro cleavage and polyadenylation of simian virus 40 late pre-mRNAs. Mol. Cell. Biol. 7: 1518-1529.

Shi, Y., Seto, E., Chang, L.S., and Shenk, T. 1991. Transcriptional repression by YY1, a human GLI-Krüppel-related protein, and relief of repression by adenovirus E1A protein. Cell 67: 377-388.

Sondek, J., Bohm, A., Lambright, D.G., Hamm, H.E., and Sigler, P.B. 1996. Crystal structure of a G-protein $\beta \gamma$ dimer at 2.1A resolution. Nature 379: 369-374.

Streit, A., Koning, T.W., Soldati, D., Melin, L., and Schümperli, D. 1993. Variable effects of the conserved RNA hairpin element upon $3^{\prime}$ end processing of histone pre-mRNA in vitro. Nucleic Acids Res. 21: 1569-1575.

Strub, K., Galli, G., Busslinger, M., and Birnstiel, M.L. 1984. The cDNA sequences of the sea urchin U7 small nuclear RNA suggest specific contacts between histone mRNA precursor and U7 RNA during RNA processing. EMBO J. 3: 28012807.

Takagaki, Y. and Manley, J.L. 1992. A human polyadenylation factor is a G protein $\beta$-subunit homologue. J. Biol. Chem. 267: 23471-23474.

1994. A polyadenylation factor subunit is the human homologue of the Drosophila suppressor of forked protein. Nature 372: 471-474.

- 1997. RNA recognition by the human polyadenylation factor CstF. Mol. Cell. Biol. 17: 3907-3914.

2000. Complex protein interactions within the human polyadenylation machinery identify a novel component. Mol. Cell. Biol. 20: 1515-1525.

Takagaki, Y., Ryner, L.C., and Manley, J.L. 1989. Four factors are required for $3^{\prime}$-end cleavage of pre-mRNAs. Genes \& Dev. 3: 1711-1724. 
Kolev and Steitz

Takagaki, Y., Manley, J.L., MacDonald, C.C., Wilusz, J., and Shenk, T. 1990. A multisubunit factor, CstF, is required for polyadenylation of mammalian pre-mRNAs. Genes \& Dev. 4: 2112-2120.

Takagaki, Y., MacDonald, C.C., Shenk, T., and Manley, J.L. 1992. The human 64-kDa polyadenylylation factor contains a ribonucleoprotein-type RNA binding domain and unusual auxiliary motifs. Proc. Natl. Acad. Sci. 89: 1403-1407.

Wall, M.A., Coleman, D.E., Lee, E., Iñiguez-Lluhi, J.A., Posner, B.A., Gilman, A.G., and Sprang, S.R. 1995. The structure of the $G$ protein heterotrimer $G_{i \alpha 1 \beta 1 \gamma 2}$. Cell 83: 1047-1058.

Wu, C.H. and Gall, J.G. 1993. U7 small nuclear RNA in C snurposomes of the Xenopus germinal vesicle. Proc. Natl. Acad. Sci. 90: 6257-6259.

Wu, L., Wells, D., Tay, J., Mendis, D., Abbott, M.A., Barnitt, A., Quinlan, E., Heynen, A., Fallon, J.R., and Richter, J.D. 1998. CPEB-mediated cytoplasmic polyadenylation and the regulation of experience-dependent translation of $\alpha$-CaMKII mRNA at synapses. Neuron 21: 1129-1139.

Xing, H., Mayhew, C.N., Cullen, K.E., Park-Sarge, O.K., and Sarge, K.D. 2004. HSF1 modulation of Hsp70 mRNA polyadenylation via interaction with symplekin. J. Biol. Chem. 279: 10551-10555. 


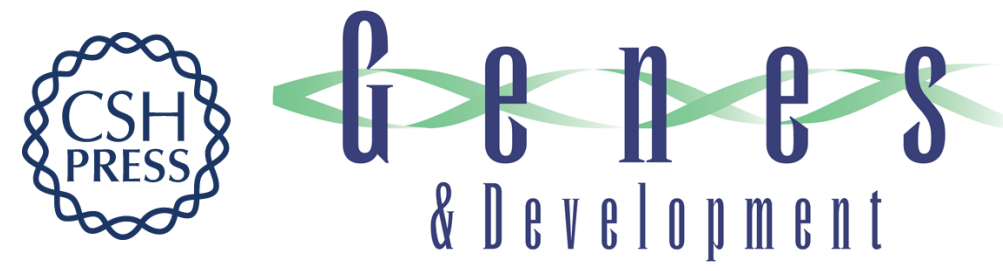

\section{Symplekin and multiple other polyadenylation factors participate in $3^{\prime}$ -end maturation of histone mRNAs}

Nikolay G. Kolev and Joan A. Steitz

Genes Dev. 2005, 19:

Access the most recent version at doi:10.1101/gad.1371105

References This article cites 62 articles, 38 of which can be accessed free at: http://genesdev.cshlp.org/content/19/21/2583.full.html\#ref-list-1

License

Email Alerting Receive free email alerts when new articles cite this article - sign up in the box at the top Service right corner of the article or click here.

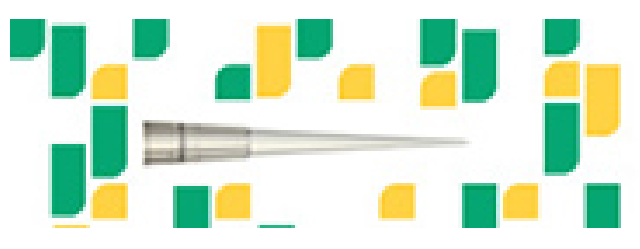

Focused on your science. 